\title{
A Survey Of Health Education And First Aid Practices In Basic Schools In Three Regional Capitals In Ghana
}

\author{
Augustine Owusu-Addo \\ REV. FR. DR. \\ Acting Head, Department Of Arts Education, \\ Catholic University College Of Ghana, Fiapre-Sunyani
}

\begin{abstract}
The research was conducted to unravel the health education offered at the basic schools and the first aid services rendered for the pupils. It was conducted in some enlightened municipalities in the middle belt of Ghana. Cross-sectional descriptive design was employed to guide the conduct of the research. Head teachers and classroom teachers provided data to address the research problem. The research unveiled that the pupils in the schools enjoy health education programmes covering varied health issues albeit inadequate. The research also revealed that first aid is provided for pupils in the schools to cater for minor health conditions, reduce pains and sustain victims till experts come in. The staff however encountered various challenges in performing both health education and first aid services in the schools. It is then essential for educational authorities in the regions to rekindle and re-double their efforts in resourcing basic schools, their head teachers and the teachers empower to deliver these services in the schools.
\end{abstract}

Key words: Students' health needs, health education, first aid, basic schools and injuries.

\section{INTRODUCTION}

The responsibilities of head teachers are vast and varied, which transcend management of teachers, students and material resources of schools. The responsibilities encompass planning, staff personnel services, student personnel services, curriculum development, staff appraisal, financial management and school-community relationship (Atta, Agyamin-Boateng, \& BaafiFrimpong cited in Esia-Donkoh, 2014, Ojo \& Olanija, 2008). One of the student personnel services rendered by head teachers is to ensure the welfare and wellbeing of students during school hours. Head teachers therefore in collaboration with their teachers and/or health personnel ensure that students have healthy life to enjoy their academic work in school. As a say goes, a sound mind resides in a healthy body. So sound mind and healthy body engender smooth academic work. Certainly, students need to be healthy in order to learn and perform well academically, and this makes health education relevant and important (WHO, Technical Report Series, 2007) in schools. This responsibility accounts for organisation of health education for both teachers and students, training of teachers and provision of some health resources to handle minor health conditions that pupils experience in the school. Head teachers, as administrators, and teachers are mindful of this fact and consequently endeavour to provide the necessary resources and support to achieve that end. Undoubtedly, schools have long played important and essential roles in providing pupils with healthy learning environment. Educational systems have indeed made school health policies an agenda. For instance, in 1992, the Ghana Education Service (GES) instituted a School Health Education Programme (SHEP), which has been running since then. The major goal of the programme is "to ensure the provision of comprehensive health and nutrition education and related support services in schools to equip children with basic life skills for healthy living, which will lead to 
improvements in child survival and educational outcomes, including school enrollment, retention and academic performance" (Mooijman, Esseku \& Tay, 2013).

School health policies should aim to create a healthy physical and psycho-social environment for all students and staff, and to make the school a model of best practice for the whole community (Howard-Barr, 2008). Effective health education programmes in schools are among the key forces in addressing the health risks and needs of children of school going age (Allensworth \& Kolbe, 2007, Fabiyi \& Blumenthal, 2001, Kolbe, Ventura \& Martin., 2001, Lohrmann, Weiss \& Kelley, 2007, Marshall, Botvin, Bake, Dusenbury \& Botvin, 2000). According to UNESCO (2008), effective school health education needs to be implemented within the broader context of a comprehensive school health approach covering a combination of skills-based health education with school health policies, safe and secure learning environments and school health services. Health education has the potency to improve the health of pupils to pursue education to the best of their ability.

\section{Relevance of school health programmes}

Since school-based health services have been shown to reach underserved populations and expand access to care school-based services may largely benefit low-income and racial minority students, as well as other students who lack alternative healthcare options (Juszczak, Melinkovich, \& Kaplan, 2003). Children who are taught in schools to acquire essential health related knowledge and skills are not only less likely to engage in health-compromising behaviour as adolescents, but they are more likely to carry the knowledge and skills into adulthood and lead healthier lifestyles (Del Rosso \& Marek, 2006). A research has disclosed that healthy children are more likely to attend school regularly and they are also more likely to perform better in their academic work (Del Rosso \& Marek, 2006). Finally, children often pass on health-related knowledge and skills acquired from schools to parents and other members of their families. As a result, school-based health education programmes are reckoned to benefit not only students but family members and the community as well (WHO, 2007). The rippling effects of school health programmes signal the need for an investigation into the extent to which basic schools organise them especially for those in the urban centers for the edification of their clientele, the pupils and consequently their families and friends.

School health programmes entail several components such as health screening, health education and physical fitness. According to Carlson (2000), to address the educational and health needs of students, it is necessary to first assess their physical health and well-being. Health screening techniques allow for early identification of suspected abnormalities. School nurses should utilize this resource and become involved with Physical Education staff as these events and programmes emerge (Bartlett, 2001). Schools, even those with limited resources, can do a great deal to improve students' health and thus educational outcomes (UNESCO, 2008). This partly accounts for the view that effective health education programmes in schools are considered to be among the key forces in addressing the health risks and needs of children of school going age (Allensworth \& Kolbe 2007, Fabiyi \& Blumenthal 2001, Kolbe et al., 2001, Lohrmann et al., 2007, Marshall et al., 2000). There is every reason therefore for schools to take health education very seriously.

It needs to recognise delivering in health education in school faces a huge challenge of personnel. According to Hahn, Teutsch, Rothenberg and Marks (2006), professional development programmes are crucial to enable current teachers to implement state-of-the-art health education. This is because teachers are expected to perform these responsibilities alongside their core teaching roles. Meanwhile most teachers do not have adequate requisite training to that effect. Hamburg (2004) found that lack of teacher training as a significant 
obstacle to the implementation of quality health education programmes. A research conducted by Collins (2001) indicated that health education teachers may have had limited pre-service preparation in the field, 48 percent of classroom health teachers had accumulated enough credits to be certified, although only 9 percent of the infused health teachers were certified in health or a combination of health and physical education. Hamburg (2004) also observes lack of teacher training as a significant obstacle to the implementation of quality health education programs.

\section{First Aid in Schools}

To ameliorate pupils' ill-health conditions, schools are supposed to offer first aid services. Thus, school authorities and teachers handling minor health conditions is a first aid issue prior to the coming in of health experts. First aid is regarded as the assessments and interventions that can be performed by a bystander such as a teacher immediately with minimal or no medical equipment (Guidelines for First Aid, 2005). The main objective of providing first aid is to reduce suffering, promote healing process and prevent damage. According to a report, injuries are a leading cause of death, hospitalization and disability throughout the world accounting for $9 \%$ of all deaths and $16 \%$ of the burden of disability annually (Priyangika , \& Hettiarachchi, 2015). The prognosis of any injuries subsequent to accidents largely depends on the management provided to the victim in the first minutes immediately following the incident. This reflects the major importance of the first-aid provided to the victim, which may sometimes be life-saving (Spinks, Mcclure, Bain, \& Macpherson, 2006)

Teachers provide emergencies in the school. With this, teachers can adequately address health needs of the children especially during emergencies (Gulani 2005). Most often than not, death occurs due to lack of basic knowledge in first aid or a delay in reaching appropriate medical care. Providing an immediate care or attention can also reduce injury, or lower morbidity and mortality rates (Park, 2009). Teachers therefore serve as important first aiders. Hence, the need for them to acquire first aid knowledge and skills to protect and save the lives of these vulnerable children under their care (Olympia et 'al, 2005). Thus, in order to ensure a holistic approach to the safety of school children, a clear understanding of the teachers' practical experience about first aid administration is very crucial. (Kids in the house, 2016)

It is essential for teachers to acquire enough first aid training through more advanced teaching strategy to keep school children safe and healthy throughout the school day (Baser, Çoban \& Tasç1, 2007). Facilitating the classroom teacher's capacity to prevent injury and promote child safety during school hours is a major concern (Khanom et'al, 2013). Timely administration of first aid in response to injuries and medical emergencies will help to reduce complications, the cost of treatment and mortality among children (Sapien \& Allen, 2001).

\section{JUSTIFICATION FOR THE STUDY}

Ensuring that children are healthy and are able to learn is an indispensable component of an effective educational administrative system of heads of schools. Since students spend a major part of their lives in school, schools are a good place to influence healthful living before harmful habits are established (Howard-Barr, 2008). Besides, in the absence of parents, schools are the best place to give care to children where teachers serve as pseudo parents. In view of that schools need to have professionally trained teachers with some skills in the administration of basic first aid (Sunil, Kulkarni, Srinivas, Prakash, Hugara \& Ashok, 2013, Muneeswari et’al, 2014).

Again, sick bays are usually provided at senior high schools which same cannot be said about the junior high schools. As the junior high schools do not have such health facilities and staff, 
how they manage minor health conditions and injuries ought to be a concern for educationists and researchers for the good of stakeholders of education. Additionally, students of junior high schools are young and can cause a lot of injuries to themselves and mates. The mental and physical abilities of children are also not developed enough to allow them to protect and defend themselves (Bhatia,.Puri, Mangat, \& Kaura, 2010). These and other issues triggered a study into how basic schools offer health education and provide first aid services for their pupils.

Another research for this research lack systematic inquiry into these in schools in less developed countries like Ghana. Much research attempts have not been directed at the health education in basic schools as well as availability of needed resources to handle minor health issues in the country. It is in the advanced nations that prior research efforts have been expended in this direction. For example, a study was conducted in Europe, which disclosed that all teachers needed to learn first aid themselves and then teach pupils, right from nursery school level. The teachers also realised the need to apply basic first aid in the classrooms (Ammirati, Gagnayre, Amsallem, Némitz, \& Gignon, 2014). Another study was conducted in the United States of America; (USA), which showed that only 5.4\% of the teachers received first-aid training. Majority of them also did not update their first aid training (Abernethy, et'al, 2003). A study was also undertaken to assess the awareness, attitudes and practices of first aid among school teachers and first aid facilities in schools in Mangalore, a coastal city in south India (AlRobaiaay, 2013). Yet another study was conducted to assess the awareness, attitudes and practices of first aid among school teachers in India. Reasons for not undergoing training in first aid as lack of opportunity, lack of statutory requirements for compulsory training, and lack of time emerged from the study. Studies that were executed in Europe urged all teachers to learn first aid so as to teach pupils, right from nursery to basic school level. Teachers were also encouraged to apply first aid ideas in classrooms (Ammirati et'al, 2014). The foregoing studies unequivocally highlight a gap in knowledge on what pertains in the Ghanaian basic schools, hence this study. The current research was conducted to give baseline data to instigate further ones in the country. It is also provides understanding of the situation on the ground and add to the stock of scanty literature on health education and first aid services offered in schools. The outcomes of the research then contributes to knowledge.

\section{RESEARCH QUESTIONS}

The research was guided by the following questions:

1. What health services are provided for the basic schools pupils?

2. What facilities are available in the basic schools to promote health education and first aid?

3. How trained are the staff who provide first aid services in the basic schools?

4. What resources are available in the schools for first aid services?

\section{METHODOLOGY}

The concurrent mixed research approach, using descriptive survey design was employed to gather data for the study. This research approach was deemed expedient as both qualitative and quantitative data was needed to address the research problem. Mixed methods aided to gather both qualitative and quantitative data from the head teachers and teachers to adequately deal with the problem under study.

The research was done in basic schools in the regional capitals of the three newly created regions in the middle belt of Ghana. The regional capitals, which are all of municipal status are Sunyani for the Bono region, Goaso for the Ahafo region and Techiman for the Bono east region. Stratified sampling method, which is a probability sampling technique, was used to 
select the schools to participate in the survey. The schools were stratified into faith-based and non-faith-based. In each municipality, three faith based schools and three non-faith-based schools were randomly sampled. At the end of the selection process, eighteen (18) schools were selected to participate in the survey.

Head teachers and teachers of the basic schools in the municipalities formed the target population while those in the selected schools constituted the accessible population. As a census survey, all head teachers and teachers of the selected schools were purposively sampled. A total of 146 respondents made up of 18 head teachers and 128 teachers participated in the research.

Questionnaire and interview guides were prepared to collect quantitative and qualitative data from the teachers and head teachers respectively. The research instruments were subjected to expert review to determine the face and content validity before they were pre-tested. The pretest was done and cronbach alpha reliability was used to determine the reliability which was $\mathrm{r}=0.83$ for the questionnaire. Data was gathered from both teachers and head teachers for triangulation purposes. Triangulation refers to the application of different methods and/or sources of data collection and analysis which complement each other so that overlapping and different facets of the issues emerge, and accuracy and validity of findings can be enhanced (Creswell Plano \& Clark, 2007). The feedback from the head teachers complimented the results from teachers.

The quantitative data of the research were analysed using SPSS and the results are presented in tables. However, content analysis was done with the qualitative data and the results are presented thematically.

\section{RESULTS AND DISCUSSION}

The results are presented in three parts. Part one shows the demographic characteristics of the respondents. Part two presents responses of the teachers and head teachers on health education while part three covers responses of the teachers and head teachers on first aid services.

\section{Part one: Demographic characteristics of respondents}

The first table shows socio-demographic data of both the head teachers and teachers who took part in the research. The personal data which were of interest to the researcher are gender, age, marital status, educational attainment and years of teaching experience. 
Table 1; Socio-demographic Characteristics of Participants

\begin{tabular}{|c|c|c|c|}
\hline & RESPONSE & $\begin{array}{c}\text { FREQUENCY } \\
(\mathrm{N}=8)\end{array}$ & $\begin{array}{l}\text { PERCENTAGE } \\
\% \\
\%\end{array}$ \\
\hline \multirow[t]{4}{*}{ Gender } & Male & 82 & 52.6 \\
\hline & Female & 74 & 47.4 \\
\hline & Total & 156 & 100.0 \\
\hline & $20-30$ & 40 & 25.6 \\
\hline \multirow[t]{3}{*}{ Age } & $31-40$ & 52 & 33.3 \\
\hline & $41-60$ & 64 & 41.1 \\
\hline & Total & 156 & 100.0 \\
\hline \multirow[t]{3}{*}{ Marital Status } & Married & 124 & 79.5 \\
\hline & Single & 32 & 20.5 \\
\hline & Total & 156 & 100.0 \\
\hline \multirow[t]{5}{*}{ Educational Qualification } & Bachelor's Degree & 76 & 48.7 \\
\hline & PGDE & 26 & 16.7 \\
\hline & Dip in Education & 54 & 34.6 \\
\hline & Total & 156 & 100.0 \\
\hline & $1-5$ years & 20 & 12.8 \\
\hline working & $6-10$ years & 48 & 30.8 \\
\hline \multirow[t]{3}{*}{ experience } & $11-15$ years & 53 & 34.0 \\
\hline & More than 16years & 35 & 22.4 \\
\hline & Total & 156 & 100.0 \\
\hline \multirow[t]{3}{*}{ Designation } & Head teachers & 18 & 11.5 \\
\hline & Teachers & 138 & 88.5 \\
\hline & Total & 156 & 100.0 \\
\hline
\end{tabular}

Source: Field Data, 2017

The data analysis on sex distribution of the subjects indicates a slight male dominance in both headships and teaching positions in the three regional capitals. The head teachers and teachers are also relatively old as more than 40 percent of them are over 40 years. The relatively old staff may have good knowledge and experience in health education and first aid to put at the disposal of the pupils they handle in the schools.

All the heads and teachers also have professional training in education either at the college or university level. In Ghana, the colleges of education offer diplomas while the universities offer degree in education and postgraduate diploma in education awards for students who successfully pursue their programmes. Such professionals may acquire some useful knowledge that could be useful for handling health related issues that affect their pupils.

\section{Part two: Responses on health education in the schools}

A question was posed to verify if the school provides health education for the pupils? The responses of the teachers are presented in table 2 below. 
Table 2: Responses on provision of health education in the school

\begin{tabular}{|c|c|c|c|c|}
\hline & \multicolumn{2}{|l|}{ YES } & \multicolumn{2}{|l|}{ NO } \\
\hline & FREQUENCY & $\%$ & FREQUENCY. & $\%$ \\
\hline $\begin{array}{l}\text { Does the school provide health education for } \\
\text { pupils? }\end{array}$ & 114 & 82.6 & 24 & 17.4 \\
\hline $\begin{array}{l}\text { Does the school organise health education } \\
\text { regularly for pupils? }\end{array}$ & 52 & 37.7 & 86 & 62.3 \\
\hline $\begin{array}{l}\text { Is it only the head teacher and teachers who } \\
\text { provide health education for pupils in your } \\
\text { school? }\end{array}$ & 6 & 4.3 & 132 & 95.7 \\
\hline $\begin{array}{l}\text { Is it both staff of the school and health } \\
\text { personnel who provide health education for } \\
\text { pupils in your school? }\end{array}$ & 132 & 95.7 & 6 & 4.3 \\
\hline
\end{tabular}

On the issue of provision of health education for the pupils in the school, it came out that an overwhelming majority responded that health education is organised for the pupils of the schools. The majority of the teachers who responded in the affirmative that the pupils in their schools are not denied health education are 114 representing over 80 percent of the teacherrespondents. The responses however indicate that although pupils in the schools enjoy health education on scarcely, it is scarcely done. This is because majority of the teachers, who are 86 representing 62.3 percent of them asserted that health education is not organised regularly for the pupils. It less than 40 percent of the teachers hold the view that health education is regularly provided for the pupils in their schools.

Concerning who provides health education for the pupils, it came to light that both staff of the schools and health personnel do that. 132 teachers representing more than 95 percent responded affirmatively that both staff of the school and health personnel do offer health education for the pupils. The responses clearly portray there is a co-ordinated efforts by the schools and health services providers in offering health education for pupils to have a healthy life and consequently the state of mind that promotes academic work. The results suggest that SHEP is working in the schools in the regional capitals.

The other question that was posed to the teachers sought to unveil the kinds of health issues that are usually discussed during health education in the schools. The responses provided are shown in the table below.

Table 3: Health issues discussed during health education in the schools

\begin{tabular}{|l|c|c|c|c|}
\hline & \multicolumn{2}{|c|}{ YES } & \multicolumn{2}{c|}{ NO } \\
\hline & FREQUENCY & \% & FREQUENCY & \% \\
\hline Personal hygiene & 126 & 91.3 & 12 & 8.7 \\
\hline Sex education & 94 & 68.1 & 44 & 31.9 \\
\hline Communicable disease & 90 & 65.2 & 48 & 34.8 \\
\hline First aid & 58 & 42.0 & 80 & 58.0 \\
\hline Nutrition & 45 & 32.6 & 93 & 67.4 \\
\hline Mental health & 15 & 10.8 & 123 & 89.2 \\
\hline Physical fitness & 42 & 30.4 & 96 & 69.6 \\
\hline Other health issues & 138 & 100 & 00 & 00.0 \\
\hline
\end{tabular}

With respect to the issues that the pupils are usually educated on in the schools, prominent among them are personal hygiene, sex education and communicable diseases. 126 teachers representing over 90 percent indicated that the pupils do receive education on personal hygiene with less than 10 percent who answered "No" to the question. Similarly, 94 teachers 
representing over 68 percent answered that sex education is offered by health educators to pupils in the schools. Furthermore, over 65 percent of the teachers said that issues on communicable diseases are discussed during health education for pupils to gain more insights into it. However, according to the results, the issues that do not gain prominence in the health education provided for the pupils in the schools are first aid, nutrition, physical fitness and mental health. The responses show that barely over 40 percent of the teachers indicated that the pupils are educated on first aid during health education given in the schools. Again, barely over 30 percent respectively of the teachers pointed out that the pupils do receive education on nutrition and physical fitness or physical health.

The head teachers provided the following responses on health education offered in the schools. Do you provide health education for the pupils?

All the head teachers responded in affirmative indicating that their schools have been organising health education for the pupils in their schools. Some head teachers intimated that due to their SHEP programme, health education programmes are offered for their pupils. Two of them said:

we have a SHEP programme, which has been a good source of health education for our pupils.

Who handle health education in the school?

According to the head teachers, health education is not organised by only one group of personnel. The teachers and trained health personnel have been providing worthy education ideas to the pupils of the schools. At times, the SHEP co-odinators at the district arrange and offer education on some worrying heath issues for our pupils. At times too, our teachers who have good knowledge about some diseases are made to prepare and educate the pupils about those conditions. As a head teacher reiterated,

some of our science teachers are good at educating our pupils when there are

outbreaks of diseases which our pupils need to know the causes, effects and

protective mechanisms so that they would not be affected.

How frequently is it conducted?

On the frequency of organisation of health education in the schools, the head teachers indicated that, it is not frequently done. They organise it once in a while. A head teacher said, due to time factor, we don't usually do. It is also even difficult to get the facilitators to provide the education on the kind of health issues you want for your pupils.

Both teachers and head teachers' responses smack off inadequate provision of health education in the pupils. Consequently, one will not be far from right if he/she avers that the health education provided for pupils in the schools in the regional capitals in the newly created regions is not adequate. This would not give the pupils the health knowledge and skills they would carry into adulthood and have healthy lifestyles as espoused by Del Rosso and Kaplan (2006). The non-regular provision of health education for the pupils may be due to lack of professional training in the subject as found by Hamburg (2004). In an earlier study Collins (2001) had discovered that majority of teachers had not had training on health education, which has the propensity to hinder implementation of health programmes in schools.

\section{Part two: Responses on first aid services in the schools}

The issue of first aid is very vital in the management of school children. The study therefore shown interest in how the schools handle it to enable the pupils have sound mind and body for academic and social work. A question was posed to find out whether the schools provide first 
aid services to pupils during school hours? The answer was clearly "Yes". All the teachers replied that they offer some kind of first aid services when any pupils show some signs of illhealth or injury during contact hours.

The next question was "who provides first aid to pupils in the schools"? The responses indicate that it is the teachers who handle the situation. It was highlighted that mostly teachers who happen to be at the scene of the incidence which demands attention offers the service.

Have you received training on first aid?

Majority of them indicated that they have not been formally trained in first aid services. A few said that they have had some talks on first aid while some indicated that they read, listen to radio and watch TV programmes on first aid. Yet some others indicated that they use their experience to offer first aid services. The responses generally signal that majority of the teachers do not have adequate knowledge on first aid yet they endeavour to help pupils when the need arises prior to the coming in of health personnel either at the school or health facility. A fellow-up question to those who claimed to have received some form of training on first aid services was "do you receive regular training and education on first aid?"

Majority of them did not respond in the affirmative. Meaning they do not update and upgrade their knowledge and competence in first aid services. Possibly, they may not be able to apply state-of-the art first aid services as they may not be in tune with current knowledge and skills in the subject matter.

A question was also posed to find out whether the teachers think formal training on first aid is important. The response was emphatically "Yes", The explanation that some of them gave to support their stand are that, as a skill-based activity, we need to be trained and we are not health professionals so training is vital for.

The next issue was to find out the first aid items that are available for the service in the schools.

Table 4: Items in first aid for services in the schools

\begin{tabular}{|l|c|c|c|}
\hline & $\begin{array}{c}\text { NOT } \\
\text { AVAILABLE }\end{array}$ & $\begin{array}{c}\text { AVAILABLE BUT } \\
\text { INADEQUATE }\end{array}$ & $\begin{array}{c}\text { AVAILABLE AND } \\
\text { ADEQUATE }\end{array}$ \\
\hline Drugs & $22(15.9)$ & $14(10.2)$ & $102(73.9)$ \\
\hline Antiseptic & $15(10.9)$ & $28(20.3)$ & $95(68.8)$ \\
\hline Bandage in pack & $74(53.6)$ & $12(8.7)$ & $52(37.7)$ \\
\hline Rescue blanket & $60(43.5)$ & $58(42.0)$ & $20(14.5)$ \\
\hline Scissors & $41(29.7)$ & $32(23.2)$ & $65(47.1)$ \\
\hline Sting relief wipe & $52(37.7)$ & $32(23.2)$ & $54(39.1)$ \\
\hline Sterile eye wash & $67(48.6)$ & $26(18.8)$ & $45(36.6)$ \\
\hline Other items & $57(41.3)$ & $42(30.4)$ & $39(28.3)$ \\
\hline
\end{tabular}

The data in the table that most of the items needed for first aid services are either not available or available but inadequate. These include bandages, brackets, sting relief wipe and sterile eye wash. According to the results, the only items available in the schools and are adequate are drugs, antiseptics and scissors.

The head teachers also provided the following responses on first aid in the schools. Does the school provide first aid services for pupils?

The unanimous response was that as schools with many pupils who fall sick here and there, first aid was offered in the schools. When pupils start showing signs of ill-health, arrangements 
are made to get health experts to attend to them. They added that even with serious ailments and injuries, teachers make the effort to resuscitate or give some medications as first aid till they get to health facilities. Some head teachers said, even though there are clinics and hospitals in town, some conditions are such that we need to do something about them to reduce pains to help save the situation. If you want to wait all the time for health personnel to come and handle the pupils' illness and injuries, it will be fatal and care is not $t$ taken, you may even lose the child

Another one said, we have been helping save the pupils by rendering this service to reduce the pains the pupils go through when they hurt themselves. Without that parents would have been suffering by losing their children who they have brought to be educated.

Who provides first aid services to the pupils?

Likewise the teachers, the head teachers replied that it is the teachers who handle first aid in the schools. They said that every teacher whose pupils experience a situation that needs first aid services make the effort to provide it. According to them, most of them have not received training on first aid. Two head teachers, however, indicated that they have some teachers on their staff who have been assigned the duty to handle first aid in their schools.

They said.

there are teachers who have been trained to do that in the schools. So any time such a situation arises, they are called in to perform that duty.

A question was then posed to find out the expertise of the teachers who offer first aid in the schools. Here again, the head teachers lamented non-professional knowledge of the teachers. It came out that although some teachers have been given some sort of education on first aid, it cannot amount to formal training in that respect. Some head teachers said, the teachers are not formally and adequately trained on first aid. However, the two head teachers repeated that some specific teachers have been trained as first aiders.

On the issue of first aid resources, most of the head teachers lamented inadequacy of the resources. They complained that there are not enough first aid facilities and items to handle first aid in the schools. For instance, three head teachers lamented, there are no special rooms in the schools for that as well the required items to perform that duty. When you need resources to help resuscitate and reduce pains of pupils, you do not them.

The head teachers provided the challenges confronting delivery of first aid in the schools as inadequate qualified personnel, facilities, supplies and financial

Both categories of respondents indicated that the pupils receive first aid services in the schools. This finding is consistent with the admonishing that teachers need to offer first aids in school to improve the health conditions of their pupils (Ammirati et al, 2014, Al-Robaiaay, 2013, Abemethy, et al, 2003). However, the teachers who usually offer first aid to pupils in the schools when they need arises lack professional training on first aid. This confirms findings of studies conducted by Al-Robaiaay (2013 and Muneeswari (2014). Their studies found that the teachers were not professionally trained in the administration of first aid. Further, they concurred that the schools did not have enough resources to offer adequate first aid to the pupils when the need be. 
The head teachers therefore requested that the co-ordination between the education service and health service needs to be strengthened to enable the health professionals to train teachers on first aids. Besides, it was suggested that continuous training for teachers to upgrade their knowledge on first aid. They also requested the authorities to provide the needed resources for teachers to handle minor health conditions of pupils while they are in school.

\section{CONCLUSION AND RECOMMENDATIONS}

Pupils, who are in their early adolescence, need good education about health issues and first aid. These are essential for their education. School authorities ought to ensure that pupils are healthy to enjoy academic work. The study unveiled that personal hygiene, sex education and communicable disease are the issues that the health education delivered for pupils in the schools. However, pupils in the schools do not usually receive education on issues such as nutrition and physical fitness. It is regrettable though. It is therefore advisable for health educators to include such issues in their health education curricular, and deliver them for the benefits of the young children. When they gain impeccable knowledge on these issues at young age, they will apply them in their lives throughout their years on earth.

The study also unraveled that first aid is offered for pupils in the schools albeit inadequate. The educational authority in the regions and the health directorate need to step up their effort in equipping teachers with first aid knowledge to enable them efficiently assist their pupils when the need arises. The outcomes of the signal that the basic schools in the study are not in a position to adequately handle the minor ailments of students when they occur at contact hours

\section{Reference}

Abernethy, L, MacAuley, D., McNally, O. \& McCann, S. (2003). Immediate care of school sport injury. Injury Prevention. 9(3), 270-273.

Al-Robaiaay, Y. K. (2013). Knowledge of primary school teachers regarding first aid in Baghdad. Al-Kindy College Medical Journal, 9, 54-9.

Allensworth, R. \& Kolbe, L. J. (2007). Low-income students and the socio-economic composition of public high schools. American Sociological Review, 74(5), 709-730.

Ammirati, C, Gagnayre, R, Amsallem, C., Némitz, B, \& Gignon, M. (2014). Are school teachers able to teach first aid to children younger than 6 years?: A comparative study. BMJ Open.

Bartlett, E. E. (2001). The contribution of school health education to community health promotion: What can we reasonably expect? American Journal of Public Health 71(12), 1384-1391.

Baser, M,, Çoban, S, \& Tasçı, S. (2007). Evaluating first-aid knowledge and attitudes of a sample of Turkish primary school teachers. Journal of Emergency, 33(5), 428-432.

Bhatia, V., Puri, S., Mangat, C. \& Kaura, T. (2010). An intervention study to strengthen first aid care in schools of Chandigarh, India. The Internet Journal of Family Practice, 8 (1), 2-21

Carlson, C. E. (2000). HIPP: A comprehensive school-based substance abuse program with cooperative community involvement. Special issue: The Virginia experience in prevention. Journal of Primary Prevention, 10(4), 289-302.

Collins, J. L., Small, M. G., Kann, L., Pateman, B. C., Gold, R. S., \& Kolbe, L J. (2005). School health education. Journal of School Health, 65(8), 302-311.

Collins, M. (2001). Promoting healthy body image through the comprehensive school health program. Journal of Health Education, 22(5), 297-302.

Connell, D .P., Turner, R. R., \& Mason, E. F. (2005). Summary of findings of the school health education evaluation: Health promotion effectiveness, implementation and costs. Journal of School Health, 55(8),b316-334.

Creswell, J. W., Plano, R. \& Clark, V.L. (2007). Designing and conducting mixed methods research, Thousand Oaks, CA: Sage Publications. 
Crosnoe, R. (2006). Knowledge, attitude and practices of school health programme among head teachers of primary schools in Egor Local Government Aera of Edo State, Nigeria. Pubmed , 13, 99-103.

Currie, J. (2005). Health disparities and gaps in school readiness. The Future of Children, 15(1), 117-121.

Del-Rosso \& Marek, Q. (2006). Improving the health of youth through coordinated school health programmes. Promotion Education, 1(4), 42-7.

Dilley, A. (2009). Making the case for school-based health: Where do we stand? Journal of Health Politics, Policy, and Law, 33(1), 3-37.

Esia-Donkoh, K. (2014). Attaining school and educational goals: Duties of head teachers of public basic schools in Ghana. Journal of Education and Practice, 5(1), 64-72.

Fabiyi, Y. \& Blumenthal, D. (2001). Health and the education of children from racial/ethnic minority and immigrant families. Journal of Health and Social Behavior, 47(1), 77-93.

Hahn, R.A., Teutsch, S.M., Rothenberg, R.B., \& Marks, J.S. (2006). Excess deaths from nine chronic diseases in the United States. Journal of the American Medical Association, 264, 2654-2659.

Howard-Barr, E. M. (2008). Comprehensive school health program. Advameg Incorporation.

Jackson, M. I. (2009). Understanding links between adolescent health and educational attainment. Demography, 46(4), 671-694.

Juszczak, L.P., Melinkovich, L. \& Kaplan, D. (2003). Use of health and mental health services by adolescents across multiple delivery sites. Journal of Adolescent Health, 32(3), 108-118.

Khanom, A. Hill, A. R., Brophy, S., Morgan, K,. Rapport, F, \& Lyons, R. (2013). Mothers' perspectives on the delivery of childhood injury messages: A qualitative study from the growing up in Wales. BMC Public Health. 13, 806.

Kids in the House (2016). 5-first-aid-tips-all-school-teachers-should-knowcomhttps://www.kidsinthehouse.com

Kolbe, L, J... Ventura, S. J. \& Martin, J. A. (2001). Health is academic: A guide to coordinated school health programs. New York: Teachers College Press.

Lohrmann, L., Weiss, O. \& Kelley, W. (2007). Reducing obesity via a school-based inter-disciplinary intervention among youth: Planet health. Arch Pediatric and Adolescent Medical Journal, 153(4), 409-418.

Marshall, L., Botvin, G. J., Bake, E., Dusenbury, L., \& Botvin, E. M. (2000). Implementation of a coordinated school health in a rural, low income community. Pubmed, 601-606.

Mooijman, A., Esseku, H. \& Tay, V. (2013). School health clubs in Ghana, Accra: Ghana Education Service.

Muneeswari, B. (2014). A study to assess the effectiveness of planned health teaching program using child-to-child approach on knowledge of selected first aid measures among school children in selected schools at Dharapuram in Tamil Nadu, India. Global Journal of Medicine and Public Health. 3(1), 277-604

Ojo, L. B., \& Olaniyan, D. A. (2008), Leadership roles of school administrators and challenges ahead in postprimary institutions in Nigeria. European Journal of Scientific Research, 24(2), 172-178.

Olympia, R. P, Wan, E. \& Avner, J. R. (2005). The preparedness of schools to respond to emergencies in children: A national survey of school nurses. Pediatrics, 116, 738-745.

Priyangika, K. G. G. \& Hettiarachchi, M. (2015). Knowledge, attitudes and practices on first aid measures among senior school prefects in Galle Education Division, Sri Lanka. Proceedings of $8^{\text {th }}$. International Research Conference, $K D U$.

Sapien, R. E, \& Allen, A. (2001). Emergency preparation in schools: A snapshot of a rural state. Pediatric Emergency Care,.17, 329-339.

Sunil, K, D, Kulkarni, P,, Srinivas, N., Prakash, B., Hugara, S, \& Ashok, N. C. (2013). Perception and practices regarding first-aid among school teachers in Mysore. National Journal of Community Medicine, 4(2), 349-352.

Spinks A. B., Mcclure, R. J., Bain, C. \& Macpherson, A. K. (2006). Quantifying the association between physical activity and injury in primary school-aged children. Ped. Vatr. Vcs., 118, 43-50.

UNESCO (2008). Focusing resources on effective school health. Retrieved from http://www. \Users $\backslash \mathrm{k} \backslash$ Documents $\backslash \mathrm{SHP}$ research $\backslash$ unesco education school health.htm

WHO (2007). Technical Report Series. Geneva. World Health Organisation. 